\title{
Ventilation Strategy for Proper IAQ in Existing Nurseries Buildings - Lesson Learned from the Research during COVID-19 Pandemic
}

Special Issue:

Special Issue on Air Quality in a Changed World: Regional, Ambient, and Indoor Air Concentrations from the COVID to Post-COVID Era (III)

\section{OPEN ACCESS}

Received: November 29, 2021

Revised: January 28, 2022

Accepted: January 28, 2022

\section{${ }^{*}$ Corresponding Author:} katarzyna.m.ratajczak@put.pozna n.pl

\section{Publisher:}

Taiwan Association for Aerosol Research

ISSN: $1680-8584$ print

ISSN: 2071-1409 online

(c) Copyright: The Author(s). This is an open access article distributed under the terms of the Creative Commons Attribution License (CC BY 4.0), which permits unrestricted use, distribution, and reproduction in any medium, provided the original author and source are cited.

\section{Katarzyna Ratajczak*}

Institute of Environmental Engineering and Building Installations, Poznan University of Technology, 60-965 Poznan, Poland

\section{ABSTRACT}

During the COVID-19 pandemic, many recommendations were made in the field of limiting the transmission of the SARS-CoV-2 virus, from which we can learn a lesson for determining ventilation strategies in strategic types of buildings (those whose closure during a pandemic is harmful to the economy, e.g., nurseries). The research was aimed at identifying recommendations in the field of ventilation and proposing a solution that would be applicable in existing buildings intended for the care of small children, and which would ensure the proper quality of the building environment, at the same time with low costs incurred by the owners. The outside air pollution $\left(\mathrm{PM}_{10}\right)$ and the climate in winter (low air temperature) were also taken into account. A strategy was proposed based on the use of decentralized units, dedicated to single rooms, thanks to which the appropriate amount of air is supplied (per person), the air is cleaned and heated in the heat recovery exchanger. It has been shown that the use of heat recovery ensures that the costs of air heating will be significantly lower than during airing. The proposed solutions require two holes in the external wall with a diameter of 160-200 mm (depending on the number of people), which guarantees the technically possible application in existing buildings. The strategy provides suitable conditions for the functioning of nurseries, but can be used in many types of buildings, in cold and temperate climates, where airing of the rooms during winter is not possible, especially in the case of locations where the quality of outdoor air is very poor. The proposed strategy may be applied during a pandemic, but also on a daily basis, because by ensuring the proper quality of indoor air, young children will have healthy and hygienic conditions for development when they are not at home.

Keywords: Ventilation strategy, Nurseries, Indoor air quality, COVID-19 pandemic, Decentralized ventilation

\section{INTRODUCTION}

\subsection{Institutions that Care for Children $<3$ Years and their Importance for Society}

Nurseries provide care for small children under the age of 3 in many countries (Kayhan and Akmese, 2012). Providing adequate care for small children is important as it favors the professional activation of women. This phenomenon was first observed as early as 1988 (European Commission Childcare Network, 1988). In 2002, Bettio and PIntenga (2004) reported that the European Union encouraged its member states to ensure that from 2010 at least $33 \%$ of children under 3 years and at least $90 \%$ of children under 3 years should be provided with organized daycare which includes appropriate education. As a result, women would be provided with the opportunity to pursue professional careers. Furthermore, this strategy would minimize long breaks in mother's careers due to the prior need for full-time childcare (Torres, 2008).

Despite these benefits to mothers, there is still a fear among parents about sending their children to daycare. Daycares have attempted to negate this hesitancy by providing home-like conditions 
and ensuring that their employees are specially trained to care for and educate children (Elfer, 2007). Additionally, when children attend daycare facilities with appropriate conditions, their emotional and cognitive development are stimulated and important social skills are encouraged through early integration with children of a similar age (Elfer, 2006). Furthermore, daycares provide children with early access to educational programs (Silva et al., 2018). Previous work has shown that it is beneficial for a child to begin appropriate educational programs at the age of at least 3 to 4 as this learning has a positive effect on absorbing higher levels of education later in life (Penn, 1995). This was further confirmed by research conducted in a group of children who did and did not attend nurseries (Oniwon, 2015). The times when care facilities for children were just for daycare are over. Currently, many nurseries even offer foreign language classes.

The COVID-19 pandemic that reached Europe in 2020 has highlighted the importance of organized care for small children. Due to the closure of the daycare facilities, parents have had to look after their children on their own, and therefore, a large proportion did not work, even remotely (Penn et al., 2020). Further, the closing of nurseries during a lockdown will likely prevent some of them from re-opening due to the economic strain elicited by the closure. The permanent close of nurseries will be a significant problem for the labor market. Additionally, much research is still being conducted to understand whether small children carry the SARS-CoV-2 virus and whether their nursery attendance may increase viral transmission. Current literature on this topic is conflicting (Okarska-Napierała et al., 2021).

\subsection{Research on Ventilation of Rooms during the COVID-19 Pandemic in 2020 2021}

During the COVID-19 pandemic, great attention was paid to the ventilation of rooms to assess which conditions were able to best protect people from infection. Most pathogens are transmitted between people (not only the SARS-CoV-2 virus). Therefore, because of people and their presence indoors, it is extremely important to ensure a proper indoor environment that prevents the transmission of pathogens (Qian et al., 2021). Studies have reported that adequate ventilation and appropriate HVAC systems can prevent the spread of the viruses; however, more research is required, particularly studies that assess ventilation in a non-hospital setting (Asanati et al., 2021; Kohanski et al., 2020; Ren et al., 2021). To err on the side of caution, some recommendations can be adapted from hospital rooms to other indoor facilities; these include (Elsaid and Ahmed, 2021) the provision of non-recirculated external air and which is changed at a high air changes per hour (ACH) (REHVA, 2021). The most effective solution is to decentralize ventilation, as this strategy has the benefit of securing the rooms where people do not stay (Guo et al., 2021; Hayashi et al., 2020). Central ventilation systems may be also used and there is no need to modify the existing systems, but a large share of outdoor air and very effective filtration must be provided (Pease et al., 2021). The REHVA recommendations stated that the virus can spread through ventilation ducts (REHVA, 2021). In a 2021 study (de Man et al., 2021), it was reported that that the use of mechanical ventilation with recirculation (to reduce the cost of ventilation) was used. In this instance, the ventilation system facilitated the infection of all the residents of a nursing home with SARS-CoV-19. The use of mechanical ventilation without recirculation reduces the risk of infection (Almilaji, 2021; Li et al., 2021; Schibuola and Tambani, 2021). Mechanical ventilation should be used indoors, however, it is often expensive and problematic to install (Ratajczak et al., 2020). Additionally, mechanical ventilation may be expensive to operate in warm climates (Aviv et al., 2021).

Adequate ventilation can be provided either by mechanical systems or by opening windows and doors (Asanati et al., 2021; Hayashi et al., 2020). However, the implementation of mechanical ventilation is indicated as the best strategy to ensure adequate air quality as ad hoc control procedures can be further proposed (Asanati et al., 2021; Stabile et al., 2021). Where possible, large airflows should be used because this dilutes the concentration of respiratory particles in the air and facilitates their removal from the indoor environment (Almilaji, 2021; Asanati et al., 2021; Li et al., 2021; Sundell et al., 2011). A large percentage of novel and reinfections by the SARS-CoV-2 virus have occurred due to poorly ventilated spaces (Burridge et al., 2021). Proper ventilation procedures should be provided, and monitoring measures should be proposed that enable the windows to be opened when necessary (Stabile et al., 2021). According to hospital ventilation studies, it is necessary to ensure a large number of air changes per hour (Gettings et 
al., 2021). For a standard hospital ward, $12 \mathrm{ACH}$ is recommended (Elsaid and Ahmed, 2021), and in other types of rooms it has been shown that $6.51 \mathrm{ACH}$ ensures that the possibility of infection is kept below 1\%; however, with the added conditions of proper mask adherence and a short exposure time (up to $3 \mathrm{~h}$ ) (Park et al., 2021). REHVA recommends 6-12 in hospitals, but generally, $5 \mathrm{ACH}$ should be used. The principle is to ensure a high number of air replacements, but reasonable (REHVA, 2021). Further, by studying the spread of bioaerosols in a gym, it was found that 4.14 air exchange is sufficient when the inlets and outlets are high in the ceiling (Blocken et al., 2021). A smaller number of air exchanges using filtration technologies has also been proposed as a wise precautionary strategy (Schibuola and Tambani, 2021).

The main disadvantage of high-efficiency natural ventilation is that while it is a theoretically cheap solution and easy to use (it is enough to simply open a window) it disturbs the thermal regulation of a room. It occurs in colder climates where additional heating may be needed to offset the benefit of increased air circulation from the outside; therefore, making it a potentially expensive solution (Blocken et al., 2020). Conversely, research carried out in warmer climates has highlighted the need for expensive air conditioning which increases the operating costs of the building when passive airing was being used (Aviv et al., 2021; Hayashi et al., 2020; Park et al., 2021). Additionally, air conditioners do not provide a fresh supply of outside air, but only cool the air from the room (Blocken et al., 2020). As such, it is not advisable to use such devices where there is a risk of contamination. An efficient way to reduce the energy demand of mechanical ventilation systems is to use heat recovery (Ratajczak et al., 2020; Schibuola and Tambani, 2021).

Air purification and filtration is another notable consideration (Almilaji, 2021; Asanati et al., 2021). Filtration is especially important in places where the outside air is polluted with particulate matter (PM). PM is not a direct cause of COVID-19 infection; however, PM has been shown to be a transporter of bioaerosols (Brągoszewska et al., 2016; Madureira et al., 2016; Nazaroff, 2016). Therefore, like hospital wards, the air introduced into rooms from the outside should be filtered to preventing the transmission of contagions (Elsaid and Ahmed, 2021; Mousavi et al., 2020). HEPA filters are the best technology to efficiently filter external air. Studies have shown that when air samples were collected with a HEPA filter, the SARS-CoV-2 virus was not present; however, it was possible to identify the virus in samples collected without the filter (Asanati et al., 2021). In Georgian schools, where frequent airing was introduced, the incidence of COVID-19 was 35\% lower. Furthermore, when filtration was applied, the incidence of COVID-19 was 48\% lower (Gettings et al., 2021). When mechanical ventilation is not used, it is important to use local, internal air purifiers equipped with HEPA filters or an equivalent filtration technology for the best possible result (Schibuola and Tambani, 2021). However, air purifiers should only be considered when existing adequate ventilation is being utilized; not as a standalone solution (Zhao et al., 2020).

Indoor $\mathrm{CO}_{2}$ concentration was initially hypothesized to correlate to the potential presence of SARS-CoV-2 virus particles, therefore, the concentration of $\mathrm{CO}_{2}$ in a room can be a good indicator of the risk for contracting the virus (Bhagat et al., 2020). However, this correlation was found to be weak. Additionally, increased $\mathrm{CO}_{2}$ concentration can be used as a parameter to indicate insufficient ventilation in a room. Whilst the dynamics of $\mathrm{CO}_{2}$ concentration and the presence of the virus may be different, $\mathrm{CO}_{2}$ concentration was thus adopted as a parameter for monitoring the ventilation of school rooms (Stabile et al., 2021). Maintaining the $\mathrm{CO}_{2}$ concentration at a certain level should guarantee adequate ventilation (Blocken et al., 2021). A $\mathrm{CO}_{2}$ concentration above $1200 \mathrm{ppm}$ can be used as a warning value. REHVA recommends a value of $\mathrm{CO}_{2}$ concentration at the level of $1000 \mathrm{ppm}$ and to use $\mathrm{CO}_{2}$ sensors with the setting of warning and limit values at which action should be taken (REHVA, 2021).

The last recommendation regards the time spent in rooms and the density of people therein. Research has shown that it is necessary to shorten the contact time between two people that do not reside in the same property (Hayashi et al., 2020). It has been estimated that for exposure times up to 3 hours and wearing a mask, with adequate ventilation, the risk of infection is less than 1\% (Park et al., 2021). A good strategy for reducing the risk of virus transmission is to reduce the number of people present in any room (Wang et al., 2021a). Due to the reduction of compaction, the air exchange for each person is de facto increased (Burridge et al., 2021). This observation agrees with the general recommendation that a minimum amount of outdoor air should be provided to prevent transmission. However, this strategy also depends on the distance between people, the number of people and the length of time spent in the room (Sun and Zhai, 2020). If 
the ventilation system is inefficient (including ventilation by airing), wearing a mask should be compulsory (Blocken et al., 2020; Geiss, 2021; Zhai, 2020).

\subsection{Research Goal}

Above recommendations were based on research conducted mainly in office buildings and schools. Such buildings are important economically strategic facilities. Further, the closure of schools and offices has resulted in people staying at home. In many instances, this situation is not conducive to efficient work and effective learning. Importantly, very little research has been conducted in nurseries, which are even more important. School children require less care from their parents than smaller children; however, children under 3 years old require constant parental care. This constant need for the care of small children coupled with the closure of daycare facilities means that parents (most often women) have to resign from work to look after their young. Because the provision of daycare for small children is extremely important, both for women so that they can actively work, but also for the children, who would benefit from the development of social skills, this study aims to suggest an appropriate ventilation strategy specific for nurseries or daycares.

The provision of mechanical ventilation in newly built buildings is not problematic. Further, in existing buildings, the introduction of mechanical ventilation may be problematic. Research conducted during the COVID-19 pandemic has shown that more attention should be paid to the buildings in which we currently operate and try to improve the indoor air quality.

This research aims to provide data to support the hypothesis that it is possible and economical to ensure the proper quality of indoor air in rooms used as nurseries in existing buildings located in a moderate climate, not through airing, but by the introduction of decentralized ventilation units.

What is more, the purpose of the research is not to identify recommendations to prevent the spread of SARS-CoV-2, but, based on recommendations from research conducted around the world during a pandemic, to use certain guidelines that should be followed during the normal operation of educational institutions. A strategy that will aim to indicate that it is possible to introduce changes to existing buildings, where the air quality is usually not good, as indicated by various studies, is needed.

\section{METHOD}

\subsection{Characteristics of Nurseries}

Nurseries are facilities that exist in most countries around the world. A typical child stays in a nursery facility for approximately 8-10 hours a day. Four different nurseries located in Poznań (Poland), a city with an estimated population of approximately 540,000 people, will be utilized in this study.

Since 2017, 15 public nurseries, 93 private nurseries, as well as 8 children's clubs have been operating in Poznań (Badam, 2017). In total, Poznań offers approximately 4,900 places in nurseries and daycares for children up to 3 years. Comparing the data on the number of available places from 2000 to 2020, there was a significant increase in the availability of places in these facilities (9004900 places, respectively). Furthermore, in 2018, Poznań was inhabited by about 24,000 children, of which 1 of 5 attended nursery.

Children most often attend the nursery between 6:00 am and 5:00 pm. Each group may include 5-30 children. In Poland, the Regulation of the Minister of Labor and Social Policy states that $16 \mathrm{~m}^{2}$ should be allocated to a group of 5 children with an additional $2.5 \mathrm{~m}^{2}$ requirement for each subsequent child enrolled (Minister of Labor and Social Policy, 2019). Each group of children is looked after by $2-3$ sitters.

In most nurseries, each group of children has two rooms, one of which is intended for play, and the other is intended for sleeping. In nurseries, around 11 o'clock, a nap lasting 2-3 hours is routine.

Two public nurseries and two private nurseries marked as A-D were selected for analysis. Table 1 presents the basic characteristics of the analyzed buildings. In all nurseries there is natural ventilation. Air quality tests conducted from December 2020 and June 2021 results are discussed in (Basińska et al., 2021). It has been shown that natural ventilation through airing and 
Table 1. Physical characteristics of the nurseries analyzed in this study.

\begin{tabular}{|c|c|c|c|c|}
\hline & Nursery A & Nursery B & Nursery C & Nursery D \\
\hline Opening hours & $6: 30-17: 00$ & $6: 30-17: 00$ & $7: 00-17: 00$ & $6: 30-16: 30$ \\
\hline Area of Playroom [m²] & 36.1 & 65.4 & 74.1 & 52.2 \\
\hline Area of Sleeping room $\left[\mathrm{m}^{2}\right]$ & 21.6 & 16.9 & 74.1 & 20.4 \\
\hline Volume of Playroom $\left[\mathrm{m}^{3}\right]$ & 90.3 & 176.8 & 200 & 141.0 \\
\hline Volume of Sleeping room $\left[\mathrm{m}^{3}\right]$ & 55.0 & 49.1 & 200 & 55.1 \\
\hline \multirow[t]{2}{*}{ Play time in the playroom } & 8:00-11:00 & 8:00-11:00 & 8:00-11:00 & $8: 00-10: 30$ \\
\hline & $13: 00-15: 00$ & 13:00-15:00 & $13: 00-15: 00$ & $13: 00-16: 00$ \\
\hline Nap time in sleeping room & 11:00-13:00 & 11:00-13:00 & 11:00-13:00 & $10: 30-13: 00$ \\
\hline Number of children in the group [people] & 13 & 20 & 32 & 20 \\
\hline Number of sitters [people] & 2 & 2 & 3 & 2 \\
\hline No of people per $\mathrm{m}^{2}$ (designed) [people per $\mathrm{m}^{2}$ ] & $2.4 / 1.44$ & $2.97 / 0.78$ & 2.2 & $2.37 / 0.91$ \\
\hline No of people per $\mathrm{m}^{3}$ (designed) [people per $\mathrm{m}^{3}$ ] & $6.02 / 3.6$ & $8.03 / 2.23$ & 5.9 & $6.4 / 2.5$ \\
\hline Average attendance of children [\%] & $66 \%$ & $68 \%$ & $76 \%$ & $80 \%$ \\
\hline No of people per $\mathrm{m}^{2}$ (real attendance) & $3.25 / 1.94$ & $4.2 / 1.1$ & 2.8 & $2.9 / 1.1$ \\
\hline No of people per $\mathrm{m}^{3}$ (real attendance) & $8.1 / 4.9$ & $11.32 / 3.2$ & 7.6 & $7.8 / 3.1$ \\
\hline
\end{tabular}

air inflow through disasters is insufficient and the concentration of $\mathrm{CO}_{2}$ in these facilities is increased, reaching maximum values of up to 4000 ppm in Facility $A$ and $B$ and 2000 ppm in Facility $D$. Due to the problem identified in that research, it was decided to analyze the problem by simulations in these and additional facilities by proposing a strategy based on scientific knowledge and suggestions developed during the COVID-19 pandemic.

Localisation of facilities as well as the climate parameters are described in Section S1 of Supplementary materials

\subsection{Simulations to Be Run to Access the Appropriate Ventilation Strategy}

Simulations will be carried out based on seven steps. Characteristic parameters and information on the use of actual nurseries from Table 1 will be used for the simulation. Based on the climate parameters where nurseries are located, 7-months corresponding to the heating period was selected as the analysis timepoints. The steps of the simulation are as follows: Step 1: Adopt different airflows; Step 2: Simulations of $\mathrm{CO}_{2}$ concentration - calculations; Step 3: Calculations of the average indoor $\mathrm{CO}_{2}$ concentration for the time of the stay in a room; Step 4: Selection of the appropriate airflow that meets the selection criteria; Step 5: Repeating Steps 1-4 if there to assess full attendance and the airflow that will be adjusted to the actual attendance (set in Step 5); Step 6: Determine the ratio of the airflow to the volume and the time spent in the room. Step 7: Defining ventilation strategy.

Simulations will be based on a complete mixing model. In fact, it is possible that the mixing of room air and supply air will not occur. This is a certain limitation. However, it was assumed that the simulations are general in nature and are to indicate some possible trends.

$$
\begin{aligned}
& c(\tau)=\left(\frac{\dot{m}_{\mathrm{CO}_{2}}}{\dot{V}_{S U}}+c_{e x}\right) \cdot\left(1-e^{-A H U \cdot \tau}\right)+c_{o} \cdot e^{-A H U \cdot \tau} \\
& c(\tau)=c_{e x} \cdot\left(1-e^{-A H U \cdot \tau}\right)+c_{o} \cdot e^{-A H U \cdot \tau}
\end{aligned}
$$

where $c(\tau)$ - Concentration of contaminants after time $\tau\left(\mathrm{dm}^{3} \mathrm{~m}^{-3}\right)$, cex - Concentration of contaminants in supply air (external air) $\left(\mathrm{dm}^{3} \mathrm{~m}^{-3}\right), c_{o}$ - Initial concentration of contamination $\left(\mathrm{dm}^{3} \mathrm{~m}^{-3}\right), \dot{m} \mathrm{CO}_{2}-\mathrm{CO}_{2}$ emission $\left(\mathrm{dm}^{3} \mathrm{~h}^{-1}\right), A H U-$ Air exchange $\left(\mathrm{h}^{-1}\right), V_{s U}$ - Supply airflow $\left(\mathrm{m}^{3} \mathrm{~h}^{-1}\right)$, $\tau$-Time (h).

Details of the procedure and subsequent steps are presented in Supplementary Materials (Section S2). 


\subsection{Assessment of Mechanical Ventilation and Airing - How Much Heat is Necessary to Warm Ventilated Air?}

Recommendations from the COVID-19 pandemic highlight the need for intensive airing. $6 \mathrm{ACH}$ is believed the negate the risk of infection (in hospitals). Here, this value will be compared with the $3 \mathrm{ACH}$. Details of the procedure and subsequent steps are presented in Supplementary Materials (Section S3).

\section{RESULTS}

\section{1 $\mathrm{CO}_{2}$ Concentration Simulations with Forced Ventilation Taking into}

\section{Account Real Attendance}

In the morning, the initial $\mathrm{CO}_{2}$ concentration in the playrooms is $500 \mathrm{ppm}$ (Figs. 1(a-d)). These values are slightly higher than the concentration in the outside air $(420 \mathrm{ppm})$. As people enter the room, mechanical ventilation should be activated which supplies the room with a strictly defined amount of outside air. Over time, the $\mathrm{CO}_{2}$ concentration increases until a stable $\mathrm{CO}_{2}$ value is achieved. The equilibrium results from the $\mathrm{CO}_{2}$ emissions of the occupants and the supplied flow of outside air. This concentration limit ranged from 700 to $1400 \mathrm{ppm}$.

After about 3 hours, the children go to the bedroom where they sleep for approximately 22.5 hours. There is no $\mathrm{CO}_{2}$ emission in the playroom during this time. The starting concentration for this period is the morning breakpoint. When the mechanical ventilation is running, the $\mathrm{CO}_{2}$ concentration drops until it reaches the value of $420-600 \mathrm{ppm}$.

In the third period, the children return to the playroom. Here, $\mathrm{CO}_{2}$ emission is reestablished, and the $\mathrm{CO}_{2}$ concentration increases until reaching the value of 700-1400 ppm. However, this is dependent on the size of the outdoor airflow and the volume of the playroom.

Children leave the playroom to the bedroom for naptime. In most cases, the bedroom is smaller than the playroom. This is because children do not need as much space to sleep as to play. Unfortunately, this causes a situation that means that the $\mathrm{CO}_{2}$ concentration is much higher in the bedrooms relative to the playroom (Basińska et al., 2019).

Fig. 2 shows simulations of $\mathrm{CO}_{2}$ concentration during a typical naptime. The sleeping room is used for approximately 2-2.5 hours per day. The initial $\mathrm{CO}_{2}$ concentration was found to be $500 \mathrm{ppm}$. $\mathrm{CO}_{2}$ emissions are the same as in the playroom and the same ventilation airflows were selected. The final concentration after 2 hours is $750-1400 \mathrm{ppm}$. Other values of $\mathrm{CO}_{2}$ concentration outside this range were obtained from sleeping rooms of different sizes. Therefore, despite the adoption of the same value of the airflow, the number of air exchanges is different.

\subsection{Selection of Appropriate Ventilation Airflow}

Table 2 reports the values of $\mathrm{CO}_{2}$ concentration for each period for the playroom and the sleeping room. The average $\mathrm{CO}_{2}$ concentration for each period, even with a small airflow was significantly lower than $1100 \mathrm{ppm}$. The appropriate ventilation airflow was selected based on the values presented in Table S2 (Supplementary Materials).

Based on simulation data, airflows were chosen which corresponded to an appropriate ventilation device from Table S2. In the case of the smallest analyzed airflow, there was no even short-term exceedances of $1500 \mathrm{ppm}$. As for a stream of $10 \mathrm{~m}^{3} \mathrm{~h}^{-1}$ per person, the average $\mathrm{CO}_{2}$ concentration was lower than the assumed $1200 \mathrm{ppm}$. But the maximum values were obtained at the end of the service life that exceeds this value.

The airflow of $15 \mathrm{~m}^{3} \mathrm{~h}^{-1}$ per person in each nursery guaranteed an average $\mathrm{CO}_{2}$ concentration lower than $1000 \mathrm{ppm}$. Unfortunately, in the case of Nursery C, providing such an air stream involves as many as 4 ventilation devices. It is a certain technical difficulty that may make the owner of the facility less inclined to apply it.

The use of the smallest airflow means that less space is required to install the ventilation units. This is an important consideration for existing buildings, especially smaller facilities where there may not be enough space for mounting holes with specific dimensions. To verify whether a small airflow would be sufficient, further simulations were carried out using the selected airflow (Table 4) and taking into account full attendance. 
(a)

$\mathrm{CO}_{2}$ concentration in playroom $\mathrm{A} 1$

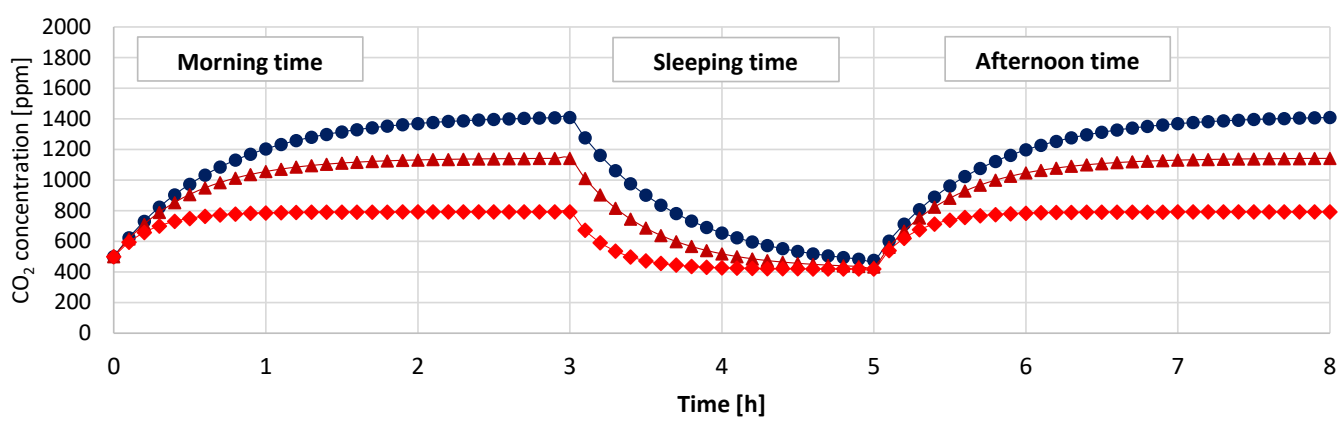

(b)

$\mathrm{CO}_{2}$ concentration in playroom $\mathrm{B} 1$

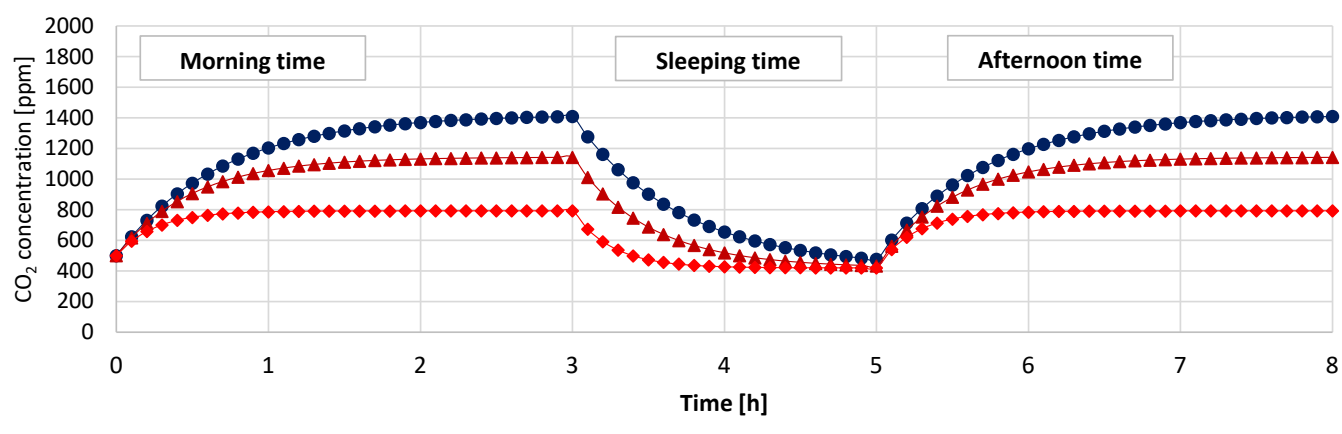

(c)

$\multimap-10 \mathrm{~m} 3 / \mathrm{h}$ per person $\quad \_-15 \mathrm{~m} 3 / \mathrm{h}$ per person $\quad \rightarrow 30 \mathrm{~m} 3 / \mathrm{h}$ per person

)

$\mathrm{CO}_{2}$ concentration in playroom $\mathrm{C1}$

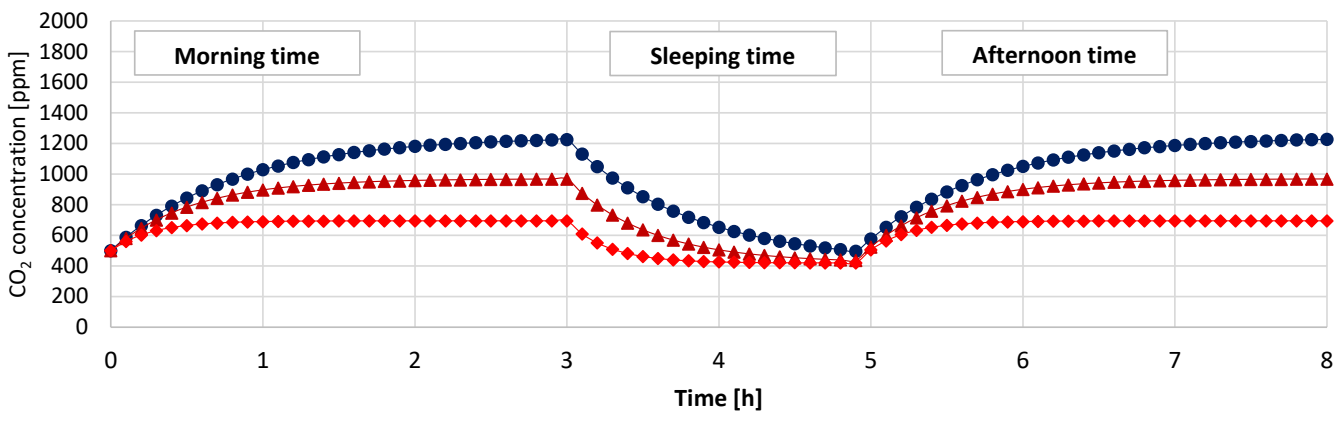

(d)

$\mathrm{CO}_{2}$ concentration in playroom D1

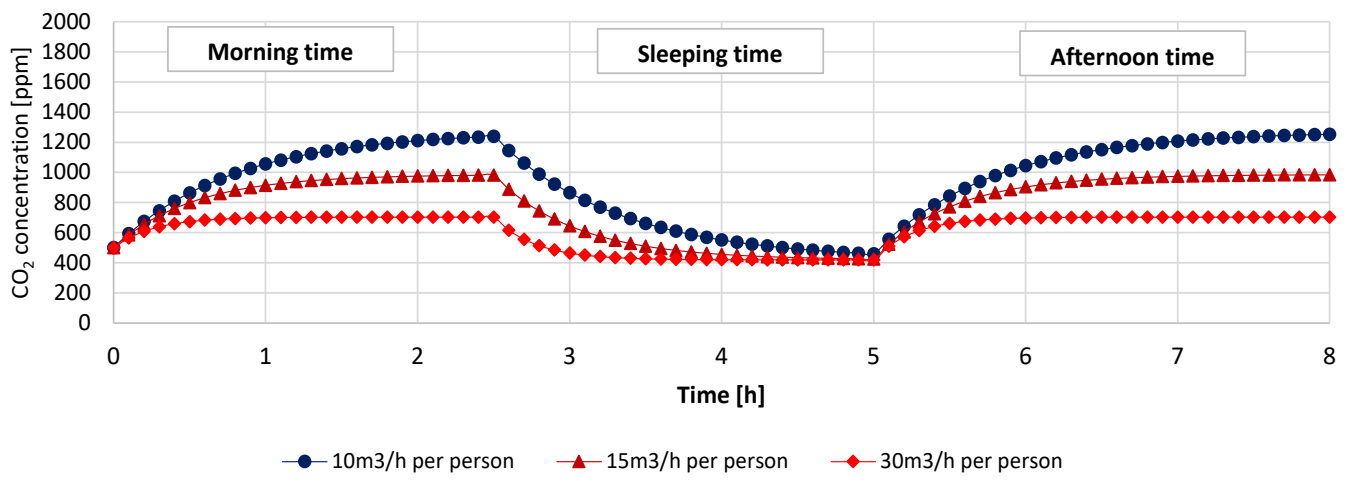

Fig. 1. $\mathrm{CO}_{2}$ concentration in the playroom divided into three periods: Morning, Sleeping time (children are in a different room) and Afternoon - (a) Nursery A, (b) nursery B, (c) Nursery C, (d) Nursery D. 
(a)

$\mathrm{CO}_{2}$ concentration in sleeping room $\mathrm{A2}$

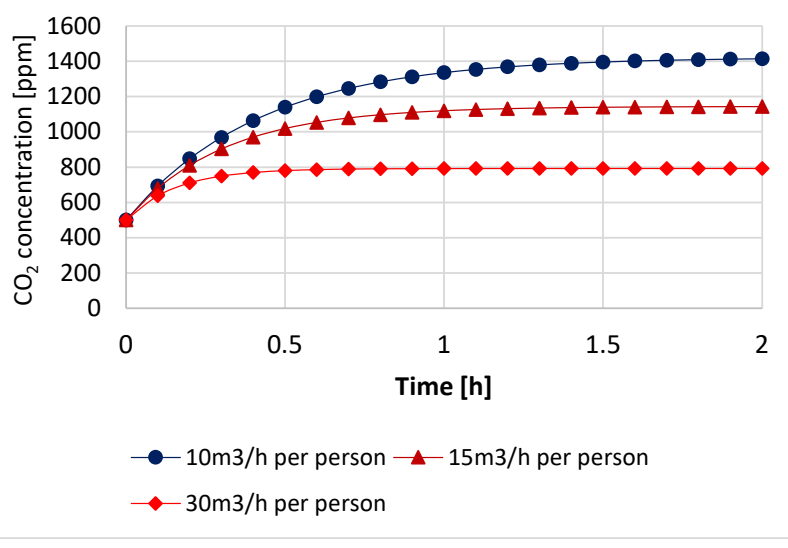

(c)

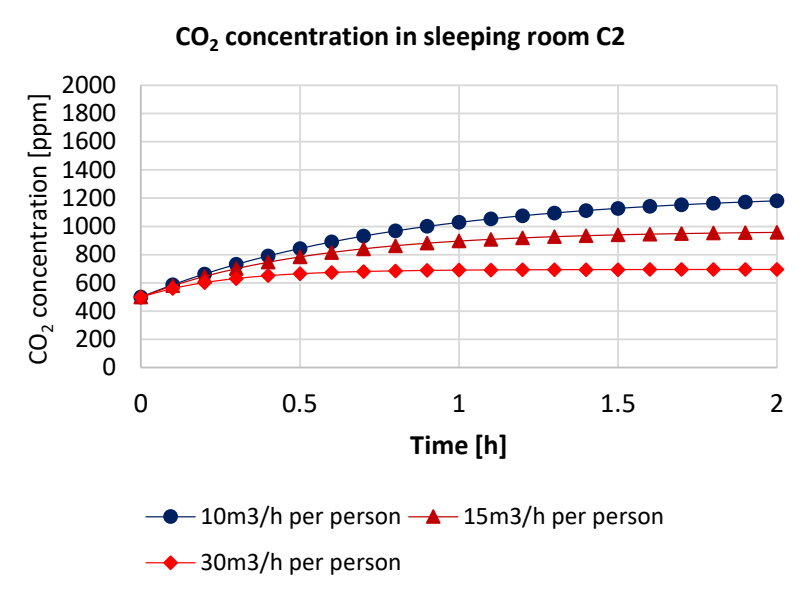

(b)

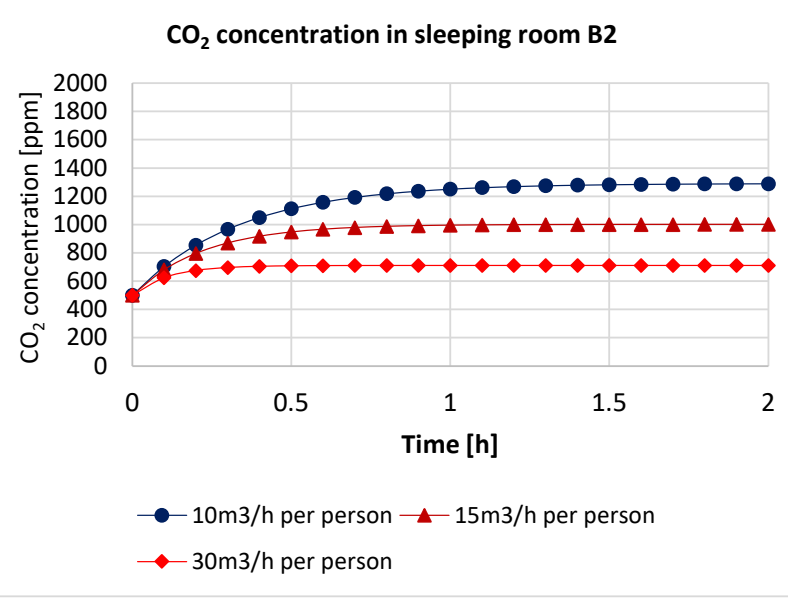

(d)

$\mathrm{CO}_{2}$ concentration in sleeping room $\mathrm{D} 2$

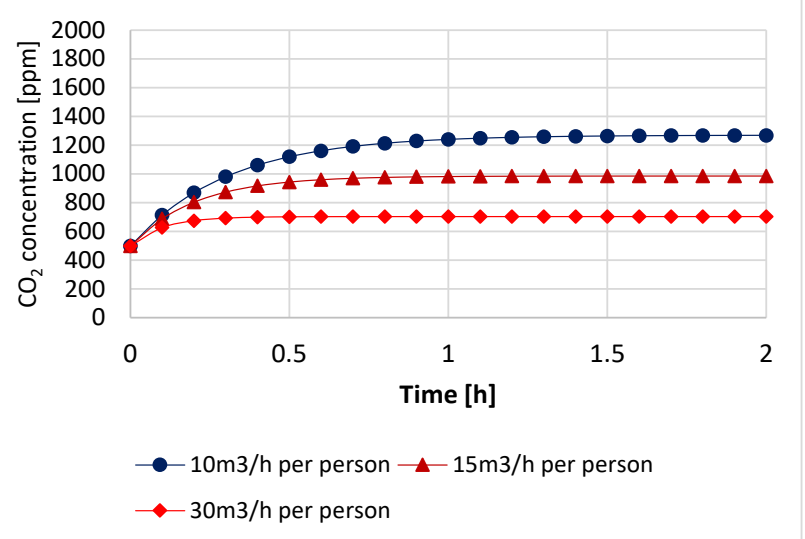

Fig. 2. $\mathrm{CO}_{2}$ concentration in the sleeping room - (a) Nursery $A$, (b) Nursery B, (c) Nursery C, (d) Nursery D.

Table 2. Selection of the ventilation airflow for Nurseries A-D based on simulation results.

\begin{tabular}{|c|c|c|c|c|c|c|}
\hline \multicolumn{7}{|l|}{ Nurseries } \\
\hline \multicolumn{7}{|l|}{ Nursery A } \\
\hline Supply airflow per person $\left[\mathrm{m}^{3} \mathrm{~h}^{-1}\right.$ per person] & \multicolumn{2}{|l|}{10} & \multicolumn{2}{|l|}{15} & \multicolumn{2}{|l|}{30} \\
\hline Supply air flow per room $V_{s u}\left[\mathrm{~m}^{3} \mathrm{~h}^{-1}\right]$ & \multicolumn{2}{|l|}{111} & \multicolumn{2}{|l|}{167} & \multicolumn{2}{|l|}{333} \\
\hline Air change per hour ACH playroom $\left[\mathrm{h}^{-1}\right]$ & \multicolumn{2}{|l|}{1.2} & \multicolumn{2}{|l|}{1.8} & \multicolumn{2}{|l|}{3.7} \\
\hline Air change per hour ACH sleeping room $\left[\mathrm{h}^{-1}\right]$ & \multicolumn{2}{|l|}{2.0} & \multicolumn{2}{|l|}{3.0} & \multicolumn{2}{|l|}{6.1} \\
\hline $\mathrm{CO}_{2}$ concentration average (Ave) and $\max (\mathrm{Max})[\mathrm{ppm}]$ & Ave. & Max & Ave. & Max & Ave. & Max \\
\hline Morning time & 1102 & 1307 & 925 & 1023 & 699 & 723 \\
\hline Sleeping time (sleeping room) & 1115 & 1313 & 930 & 1024 & 699 & 723 \\
\hline Afternoon time & 1011 & 1257 & 862 & 1011 & 676 & 723 \\
\hline Average concentration during the stay of children in the nursery & \multicolumn{2}{|l|}{1080} & \multicolumn{2}{|l|}{908} & \multicolumn{2}{|l|}{693} \\
\hline Selected air flow to the room $\left[\mathrm{m}^{3} \mathrm{~h}^{-1}\right]$ & \multicolumn{2}{|l|}{120} & \multicolumn{2}{|l|}{180} & \multicolumn{2}{|c|}{$360 *$} \\
\hline Number of holes required in the external wall & \multicolumn{2}{|c|}{$2 \times 100 \mathrm{~mm}$} & \multicolumn{2}{|c|}{$2 \times 160 \mathrm{~mm}$} & \multicolumn{2}{|c|}{$4 \times 160 \mathrm{~mm}$} \\
\hline \multicolumn{7}{|l|}{ Nursery B } \\
\hline Supply airflow per person $\left[\mathrm{m}^{3} \mathrm{~h}^{-1}\right.$ per person] & \multicolumn{2}{|l|}{10} & \multicolumn{2}{|l|}{15} & \multicolumn{2}{|l|}{30} \\
\hline Supply air flow per room $V_{S U}\left[\mathrm{~m}^{3} \mathrm{~h}^{-1}\right]$ & \multicolumn{2}{|l|}{146} & \multicolumn{2}{|l|}{219} & \multicolumn{2}{|l|}{438} \\
\hline Air change per hour ACH playroom $\left[\mathrm{h}^{-1}\right]$ & \multicolumn{2}{|l|}{0.8} & \multicolumn{2}{|l|}{1.2} & \multicolumn{2}{|l|}{2.5} \\
\hline Air change per hour ACH sleeping room $\left[\mathrm{h}^{-1}\right]$ & \multicolumn{2}{|l|}{3.0} & \multicolumn{2}{|l|}{4.5} & 8.9 & \\
\hline $\mathrm{CO}_{2}$ concentration average (Ave) and $\max (\mathrm{Max})$ [ppm] & Ave. & Max & Ave. & Max & Ave. & Max \\
\hline Morning time & 994 & 1225 & 865 & 989 & 680 & 710 \\
\hline Sleeping time (sleeping room) & 1145 & 1290 & 935 & 1001 & 694 & 711 \\
\hline Afternoon time & 937 & 1154 & 799 & 956 & 648 & 709 \\
\hline
\end{tabular}


Table 2. (continued).

\begin{tabular}{|c|c|c|c|c|c|c|}
\hline \multicolumn{7}{|l|}{ Nurseries } \\
\hline Average concentration during the stay of children in the nursery & \multicolumn{2}{|l|}{1021} & \multicolumn{2}{|l|}{866} & \multicolumn{2}{|l|}{675} \\
\hline Selected air flow to the room $\left[\mathrm{m}^{3} \mathrm{~h}^{-1}\right]$ & \multicolumn{2}{|c|}{140} & \multicolumn{2}{|c|}{220} & \multicolumn{2}{|l|}{$440^{*}$} \\
\hline Number of holes required in the external wall & \multicolumn{2}{|c|}{$2 \times 160 \mathrm{~mm}$} & \multicolumn{2}{|c|}{$2 \times 200 \mathrm{~mm}$} & \multicolumn{2}{|c|}{$4 \times 200 \mathrm{~mm}$} \\
\hline \multicolumn{7}{|l|}{ Nursery C } \\
\hline Supply airflow per person $\left[\mathrm{m}^{3} \mathrm{~h}^{-1}\right.$ per person] & \multicolumn{2}{|l|}{10} & \multicolumn{2}{|l|}{15} & \multicolumn{2}{|l|}{30} \\
\hline Supply air flow per room $V_{s u}\left[\mathrm{~m}^{3} \mathrm{~h}^{-1}\right]$ & \multicolumn{2}{|l|}{248} & \multicolumn{2}{|l|}{372} & \multicolumn{2}{|l|}{744} \\
\hline Air change per hour $\mathrm{ACH}$ playroom $\left[\mathrm{h}^{-1}\right]$ & \multicolumn{2}{|l|}{1.2} & \multicolumn{2}{|l|}{1.9} & \multicolumn{2}{|l|}{3.7} \\
\hline Air change per hour $\mathrm{ACH}$ sleeping room $\left[\mathrm{h}^{-1}\right]$ & \multicolumn{2}{|l|}{1.2} & \multicolumn{2}{|l|}{1.9} & \multicolumn{2}{|l|}{3.7} \\
\hline $\mathrm{CO}_{2}$ concentration average (Ave) and $\max (\mathrm{Max})[\mathrm{ppm}]$ & Ave. & Max & Ave. & Max & Ave. & Max \\
\hline Morning time & 1043 & 1226 & 880 & 968 & 674 & 695 \\
\hline Sleeping time (sleeping room) & 963 & 1182 & 840 & 958 & 665 & 695 \\
\hline Afternoon time & 958 & 1181 & 822 & 956 & 653 & 695 \\
\hline Average concentration during the stay of children in the nursery & \multicolumn{2}{|l|}{996} & \multicolumn{2}{|l|}{852} & \multicolumn{2}{|l|}{665} \\
\hline Selected air flow to the room $\left[\mathrm{m}^{3} \mathrm{~h}^{-1}\right]$ & \multicolumn{2}{|c|}{260} & \multicolumn{2}{|c|}{ 400* } & \multicolumn{2}{|c|}{$740 * *$} \\
\hline Number of holes required in the external wall & \multicolumn{2}{|c|}{$2 \times 200 \mathrm{~mm}$} & \multicolumn{2}{|c|}{$4 \times 200 \mathrm{~mm}$} & \multicolumn{2}{|c|}{$6 \times 200 \mathrm{~mm}$} \\
\hline Nursery D & & & & & & \\
\hline Supply airflow per person $\left[\mathrm{m}^{3} \mathrm{~h}^{-1}\right.$ per person] & 10 & & 15 & & 30 & \\
\hline Supply air flow per room $V_{S U}\left[\mathrm{~m}^{3} \mathrm{~h}^{-1}\right]$ & 180 & & $270 *$ & & $540 *$ & \\
\hline Air change per hour $\mathrm{ACH}$ playroom $\left[\mathrm{h}^{-1}\right]$ & 1.3 & & 1.9 & & 3.8 & \\
\hline Air change per hour $\mathrm{ACH}$ sleeping room $\left[\mathrm{h}^{-1}\right]$ & 3.3 & & 4.9 & & 9.8 & \\
\hline $\mathrm{CO}_{2}$ concentration average (Ave) and $\max (\mathrm{Max})[\mathrm{ppm}]$ & Ave. & Max & Ave. & Max & Ave. & Max \\
\hline Morning time & 1032 & 1238 & 880 & 982 & 679 & 703 \\
\hline Sleeping time (sleeping room) & 1164 & 1270 & 938 & 987 & 691 & 703 \\
\hline Afternoon time & 1056 & 1252 & 883 & 985 & 675 & 703 \\
\hline Average concentration during the stay of children in the nursery & 1082 & & 899 & & 681 & \\
\hline Selected air flow to the room $\left[\mathrm{m}^{3} \mathrm{~h}^{-1}\right]$ & 180 & & 260 & & $520 *$ & \\
\hline Number of holes required in the external wall & $2 \times 16$ & $\mathrm{~mm}$ & $2 \times 20$ & $\mathrm{~mm}$ & $4 \times 2$ & $\mathrm{~nm}$ \\
\hline
\end{tabular}

* Selection of two sets ventilation units ( 2 holes per the set) with a combined flow.

\subsection{Simulations of $\mathrm{CO}_{2}$ Concentration with Forced Ventilation and Full Child Attendance}

The selected airflows were inserted into the model assuming full attendance of children. The $\mathrm{CO}_{2}$ concentration was similar to those observed for the lower attendance but the concentration limits achieved were slightly higher (Table 3).

For the design of ventilation based on the number of people taking into account the lower attendance, when the more people are present the stream of air per person is lower. It causes higher $\mathrm{CO}_{2}$ concentration. To ensure proper conditions and meet the criterion of a maximum $\mathrm{CO}_{2}$ concentration below $1200 \mathrm{ppm}$, the air flow in real attendance should be $12-12.5 \mathrm{~m}^{3} \mathrm{~h}^{-1}$ per person. It would result in average $\mathrm{CO}_{2}$ concentration at the level of approximately $1000 \mathrm{ppm}$.

\subsection{General Indicators Concerning Recommended Airflow}

The rate of airflow in relation to the volume of rooms and the number of people present in the room were determined in all eight nursery rooms. Two versions have been adopted for Nursery C: when four ventilation units should be installed and when only two. The results are summarized in Table 4. For all playrooms, the average air change per hour was $1.8 \mathrm{ACH} \pm 0.4(1.2-2.0 \mathrm{ACH})$. For all sleeping rooms, this indicator is not so equal and is in the range of $2.0-4.7 \mathrm{ACH}(3.6 \mathrm{ACH} \pm$ 1.2). The average $A C H$, taking into account the playroom and bedrooms of all the buildings, was approximately $2.7 \mathrm{ACH}$. Considering the variant of using only two units, an average air exchange would be obtained 2.2 ACH. However, in that case the $\mathrm{CO}_{2}$ concentrations in the case of full attendance in Nursery C would be close to 1500 ppm and average around 1200 ppm. Additionally, when the real attendance was assumed in the simulations, the average $\mathrm{CO}_{2}$ concentration was about 1000 ppm, and the maximum did not exceed 1200 ppm. If the decision-making criterion 
Table 3. Simulation of $\mathrm{CO}_{2}$ concentration in rooms with the selected airflow and full attendance.

\begin{tabular}{|c|c|c|c|}
\hline \multicolumn{4}{|l|}{ Nurseries } \\
\hline \multicolumn{4}{|l|}{ Nursery A } \\
\hline Selected air flow to the room $\left[\mathrm{m}^{3} \mathrm{~h}^{-1}\right]$ & 120 & 180 & $360 *$ \\
\hline Supply Air flow per person with $100 \%$ of attendance $\left[\mathrm{m}^{3} \mathrm{~h}^{-1}\right.$ per person] & 8.0 & 12.0 & 24.0 \\
\hline Average concentration during the stay of children in the nursery & 1198 & 1011 & 752 \\
\hline Max concentration during stay & 1487 & 1143 & 792 \\
\hline \multicolumn{4}{|l|}{ Nursery B } \\
\hline Selected air flow to the room $\left[\mathrm{m}^{3} \mathrm{~h}^{-1}\right]$ & 140 & 220 & $440 *$ \\
\hline Supply Air flow per person with $100 \%$ of attendance $\left[\mathrm{m}^{3} \mathrm{~h}^{-1}\right.$ per person] & 7.0 & 12.0 & 23.5 \\
\hline Average concentration during the stay of children in the nursery & 1232 & 1004 & 753 \\
\hline Max concentration during stay & 1406 & 1184 & 702 \\
\hline \multicolumn{4}{|l|}{ Nursery C } \\
\hline Selected air flow to the room $\left[\mathrm{m}^{3} \mathrm{~h}^{-1}\right]$ & 260 & 400 & $750 *$ \\
\hline Supply Air flow per person with $100 \%$ of attendance $\left[\mathrm{m}^{3} \mathrm{~h}^{-1}\right.$ per person] & 8.1 & 12.5 & 23.4 \\
\hline Average concentration during the stay of children in the nursery & 1122 & 935 & 721 \\
\hline Max concentration during stay & 1397 & 1066 & 770 \\
\hline \multicolumn{4}{|l|}{ Nursery D } \\
\hline Selected air flow to the room $\left[\mathrm{m}^{3} \mathrm{~h}^{-1}\right]$ & $180^{*}$ & $260^{*}$ & $540^{*}$ \\
\hline Supply Air flow per person with $100 \%$ of attendance $\left[\mathrm{m}^{3} \mathrm{~h}^{-1}\right.$ per person] & 8.2 & 11.8 & 23.6 \\
\hline Average concentration during the stay of children in the nursery & 1210 & 997 & 735 \\
\hline Max concentration during stay & 1438 & 1039 & 772 \\
\hline
\end{tabular}

Table 4. Indicators of the size of the airflow.

\begin{tabular}{|c|c|c|c|c|c|}
\hline Airflow indicators & Nursery A & Nursery B & Nursery C & Nursery D & Nursery C* \\
\hline Number of ventilation units/Holes in external wall & $1 / 2$ & $1 / 2$ & $2 / 4$ & $1 / 2$ & $1 / 2$ \\
\hline Recommended air flow $\left[\mathrm{m}^{3} \mathrm{~h}^{-1}\right]$ & 180 & 220 & 400 & 260 & 260 \\
\hline Playroom $\left[\mathrm{m}^{3} \mathrm{~h}^{-1} \mathrm{~m}^{-2}\right]$ & 5.0 & 3.4 & 5.4 & 5.0 & 3.5 \\
\hline Playroom ACH $\left[\mathrm{m}^{3} \mathrm{~h}^{-1} \mathrm{~m}^{-3}\right]$ & 2.0 & 1.2 & 2.0 & 1.9 & 1.3 \\
\hline Sleeping room $\left[\mathrm{m}^{3} \mathrm{~h}^{-1} \mathrm{~m}^{-2}\right]$ & 9.2 & 13.0 & 5.4 & 12.7 & 3.5 \\
\hline Sleeping room $\mathrm{ACH}\left[\mathrm{m}^{3} \mathrm{~h}^{-1} \mathrm{~m}^{-3}\right]$ & 3.3 & 4.5 & 2.0 & 4.7 & 1.3 \\
\hline Air flow per person (full attendance) $\left[\mathrm{m}^{3} \mathrm{~h}^{-1}\right.$ per person] & 12.0 & 10.0 & 12.5 & 11.8 & 8.1 \\
\hline Air flow per person (real attendance) $\left[\mathrm{m}^{3} \mathrm{~h}^{-1}\right.$ per person] & 16.2 & 14.1 & 16.1 & 14.4 & 10.5 \\
\hline
\end{tabular}

* when the criterion will be to make only two holes in the wall.

for the owner were for the system to be easy in installation and with lower costs of purchasing and assembling the equipment, a version with a slightly smaller air stream might be acceptable. In existing buildings, an issue might be to allocate space for additional technical equipment. While ensuring the proper environmental conditions should be paramount and free of cost dilemmas, economically speaking, sometimes the compromises must be taken.

Data indicate that the optimal airflow that should be supplied to the rooms to achieve the assumed quality index was $11.6 \pm 1.1 \mathrm{~m}^{3} \mathrm{~h}^{-1}$ per person in the case of full attendance, and if the presence of occupants is representative of real attendance data (lower attendance), the airflow should be $15.3 \pm 1.2 \mathrm{~m}^{3} \mathrm{~h}^{-1}$ per person.

\subsection{Assessment of Airing Costs}

To assess the monetary costs of heating the air supplied to the building, costs were compared when the air is supplied by airing (the air is heated by the heating system) or by decentralized ventilation units with a heat recovery exchanger (air supply is preheated). The results are presented in Fig. 3.

The found COVID-19 recommendation states that buildings should provide adequate air exchange at a minimum rate of 6 air changes per hour. With such a large air exchange, in countries with a temperate or cold climate where the average outdoor air temperature is low, the costs of heating 


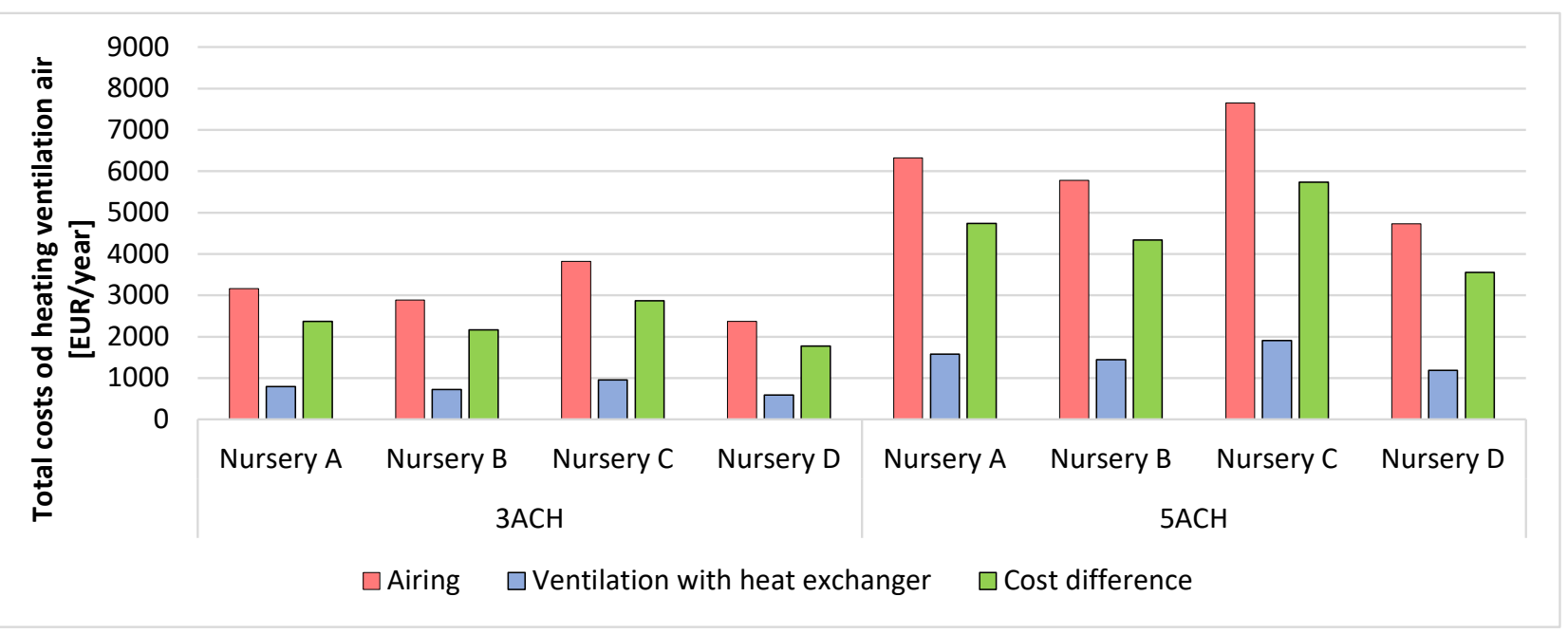

Fig. 3. Costs of heating ventilation air with different air change rates for Nursery's A-D.

the air amounted in this study to 3182 EUR to 7645 EUR per year. In this study, the highest costs, which are directly related to cubature, would be experienced by Nursery $\mathrm{C}$. However, by ensuring that the ventilation system is equipped with heat recovery heat exchangers with an efficiency of $75 \%$, this nurseries could save approximately 2387 to 5734 EUR per year. Furthermore, the cost of heating the ventilated air using a heating system with heat exchangers would be approximately 795 EUR per year for the smallest nursery (Nursery A) and 1911 EUR per year for the largest one (Nursery $\mathrm{C}$ ), using $6 \mathrm{ACH}$ as recommended. Importantly, the difference in cost between airing and the use of forced ventilation with heat recovery was significant and would possibly cover the costs of purchasing a ventilation device with the required efficiency whilst simultaneously covering operating costs.

Reducing the air stream by half, i.e., to $3 \mathrm{ACH}$ results in much lower costs that the owner of the building has to incur to ensure adequate air quality. As demonstrated by the simulations, the air flow lower than $3 \mathrm{ACH}$ can provide the required, adequate air quality for children. At the same time, such a smaller air stream makes it technically possible to introduce a forced ventilation system into the building. The ventilation costs for the $3 \mathrm{ACH}$ requirement for Nursery A-D were 1,591 to 3,822 EUR respectively. While the use of heat recovery ventilation lowered these costs from 398 to 956 EUR, and obtained saving may amount to 1,193 to 2,866 EUR.

The above analyzes are not intended to indicate that airing the rooms is expensive and should be abandoned. In conjunction with simulations, they are to indicate that a lower number of exchanges is able to ensure adequate air quality. It has also been shown that with the use of heat recovery units, air heating does not have to be expensive. This is to show potential nursery owners that the investment in a ventilation system does not have to be very expensive. And surely parents of children will be ready to bear the additional costs of providing their children with good environmental conditions.

\section{DISCUSSION}

From the simulation data, an external airflow (with a $\mathrm{CO}_{2}$ concentration of $420 \mathrm{ppm}$ ) of 12 to $12.5 \mathrm{~m}^{3} \mathrm{~h}^{-1}$ per person is recommended. Due to the continuous supply of external air (11.6 \pm $1.1 \mathrm{~m}^{3} \mathrm{~h}^{-1}$ per person), the average concentration of $\mathrm{CO}_{2}$ during the children's stay in the nursery was $987 \pm 35 \mathrm{ppm}$. In the case of real occupancy data, the airflow supplied to the room was 15.3 $\pm 1.2 \mathrm{~m}^{3} \mathrm{~h}^{-1}$ per person. This value is lower than indicated in the guidelines of various European countries (Basińska et al., 2019). Other countries that require higher airflow values specify that this airflow can be provided by natural ventilation or airing. However, in existing educational buildings with this type of ventilation, the air quality is poor (Elsaid and Ahmed, 2021).

The literature states that it is necessary to ensure the correct air change per hour (de Man et al., 2021; Elsaid and Ahmed, 2021; Gettings et al., 2021). However, the simulated data shows that 
this is not appropriate approach. For instance, in Nursery A, the number of air changes is for the playroom and sleeping room 2.0 ACH and 3.3 ACH respectively. Unsurprisingly, this data shows that each room with different dimensions, with the same number of children, requires a different number of exchanges per hour. This effect was even more extensive in Nursery $B$, where in the playroom the number of air exchanges is $1.2 \mathrm{ACH}$, and in the sleeping room was $4.5 \mathrm{ACH}$ (almost four times greater). Together, this means that if the air change per hour requirement be, for example, $3 \mathrm{ACH}$ for both rooms, it would cause the ventilation installation in the playroom to be oversized, while in the bedroom, the air quality would be unsatisfactory. In this study, the obtained $\mathrm{ACH}$ are lower than those reported in the literature, but the research was carried out in rooms for small children who emit less $\mathrm{CO}_{2}$ and bioaerosols than adults (Blocken et al., 2021).

Reducing the number of people in the room is highly recommended (Park et al., 2021; Sun and Zhai, 2020). This strategy was confirmed by the simulation results. It is the best way to ensure adequate indoor air quality by providing a larger volume of air per person. Using the same airflow, when the attendance was lower, the mean $\mathrm{CO}_{2}$ concentration during the children's stay in the nursery was about $200 \mathrm{ppm}$ lower relative to when all the children were present.

Indeed, when fewer people are in the same room, there is less emission of pollutants (including $\mathrm{CO}_{2}$ and bioaerosols, which are the result of breathing). Unfortunately, in the case of educational facilities such as schools, kindergartens, or nurseries such an approach is uneconomical, especially in the case of non-public and private facilities. Additionally, when fewer children are admitted to a daycare facility, less profit would be made by the owner or very high tuition fees will have to be paid by the parents who can send their children to nurseries to make up for the lesser numbers. Importantly, increased nursery fees would not be conducive to the professional activation of women because the costs can be deemed high enough that it would be unprofitable to start a job.

The rooms in the analyzed nurseries were used for a maximum of 3 hours. This is in line with the recommendation to reduce the time spent indoors recommended (Park et al., 2021; Sun and Zhai, 2020). Although the children stay longer in the same group, they change rooms every 2-3 hours. The room they go to is ventilated and has a low $\mathrm{CO}_{2}$ concentration when the children initially enter. Changing the room for nap time allows children to stay in rooms with good air quality (low $\mathrm{CO}_{2}$ concentration) throughout the day.

Importantly, the costs of heating the air supplied to the room are not high when heat recovery is used. Ultimately, the costs incurred depend on the size of the room. The costs associated with the operation of decentralized ventilation devices are small, therefore, the total fees related to the installation of decentralized ventilation would be very small, and the entire operating costs would be negligible, especially taking into account the tuition fees which can be around 200250 EUR per month (Ratajczak and Basińska, 2021). In further agreement with obtained data, another study showed that the costs of pumping ventilated air in decentralized ventilation units are low, and parents would have to incur a small additional cost of 10 EUR per month. This cost would cover a return on investment in 4 years.

Whilst a decentralized ventilation system has several disadvantages such as occasional improper air distribution, the need to locate the device in the external wall, small possibility of airflow regulation, often the lack of possibility to use air treatment devices, it does have undoubted advantages. It responds to the needs of using ventilation limited to one room as shown in (Hayashi et al., 2020). The advantages of facade solutions are discussed in detail in the review (ZenderŚwiercz, 2021a). Thanks to the use of a heat exchanger, the costs of heating are reduced by up to $75 \%$. Many studies have discussed the benefits of using heat exchangers for heat recovery and their impact on energy consumption and cost to the consumer (Amanowicz and Wojtkowiak, 2020a, b; Ratajczak et al., 2020; Zender-Świercz, 2021b). The correct use of ventilation devices, forced airflow, constant and controlled, are very important (Basińska et al., 2019). In combination with these ventilation devices, additional air filtration can be used to remove particulate matter while those are the carriers of bioaerosols, but also because the particulate matter itself causes respiratory and circulatory diseases (Hu et al., 2021; Wang et al., 2021b). In the case of countries with poor outdoor air quality, such as Poland, air filtration is the only strategy that can ensure proper indoor air quality. The use of a $6 \mathrm{ACH}$ external air supply could create very unhealthy conditions for young children.

Even a temporarily higher $\mathrm{CO}_{2}$ concentration, in the event of unforeseen situations, will still be better than not using forced airflow. The analyzes did not address the problem related to the 
introduction of polluted external air, which may occur in the case of the airing of rooms when there is a high concentration of particulate matter outdoors. In Poland, this problem occurs from October to April and it is related to the heating season. More detailed analyzes are presented in (Basińska et al., 2021). The conclusions from those studies indicate that airing the rooms, although it leads to a reduction in $\mathrm{CO}_{2}$ concentration, may deteriorate air quality in terms of particulate matter, which is not good for health. For this reason, airing should only be used outside the heating season, which will also result in lower costs of this process, as shown in this study. Other study (Chen et al., 2020) suggests that spending time outdoors should be avoided when the outdoor air is polluted with $\mathrm{PM}_{2.5}$. If so, the introduction of polluted air indoors without filtering should be avoided as well.

Additionally, all nurseries should be equipped with $\mathrm{CO}_{2}$ sensors, and the sitters should react if the $\mathrm{CO}_{2}$ concentration exceeds 1000 ppm i.e., the room should be aired until the $\mathrm{CO}_{2}$ concentration reaches value lower than $1000 \mathrm{ppm}$ (Stabile et al., 2021). When the outdoor air temperature is low and may cause discomfort, airing should be shorter and more often. If a decentralized ventilation system is installed, sitters should use it even outside of the heating season. When the $\mathrm{CO}_{2}$ concentration is increased, children should be moved to another room (sleeping room) and the playroom should be ventilated (even by airing). In the case of a sleeping room, its generally smaller volume may be increased by opening the door which connects the playroom and sleeping room.

The literature recommends strategies to control ventilation efficiency as a function of the number of users (Wang et al., 2021a). This is justified in the case of central installations and when user variability is high. The proposed strategy recommends that ventilation units should be selected according to the number of users so that there is no need to change the proposed airflow. Therefore, actions from the staff would only be required in crises. It is also very important to properly use the devices and regularly replace the filters, especially when the outside air is contaminated.

One more issue that can be discussed when analyzing research on SARS-CoV-2 virus spread is the connection between $\mathrm{CO}_{2}$ concentration or efficiency of ventilation and the risk of infection. This research aimed to reach some conclusions and propose the application of most of them, supplementing those with carbon dioxide simulations, showing the importance of indoor air exchange. Unfortunately, especially in existing buildings, including nurseries and schools, ventilation is insufficient to maintain $\mathrm{CO}_{2}$ at a proper level (around $1000 \mathrm{ppm}$ ). In this case, it is almost impossible to ensure that no diseases, including COVID-19, are spreading. However, scientific research shows that proper air exchange, often defined by $\mathrm{CO}_{2}$ concentration, can reduce the risk of infection. Bhagat et al. (2020) stated that $\mathrm{CO}_{2}$ may be a marker of good ventilation and concentration below 1200 ppm lowers the risk of infection by the viruses. The ventilation strategy proposed in this study is a response to the literature recommendations created during the research during the COVID-19 pandemic in the years 2020-2021. It is also a response to the invitation indicated in the literature (Fadaei, 2021; Villanueva et al., 2021) to search for ventilation strategies that can be used in educational buildings and to try to define the effective ventilation for existing buildings. However it is impossible to provide general guidelines with certainty for all rooms in all buildings because each building is different and the guidelines should be adapted to its users, location, and way of usage. This study defined a ventilation strategy to provide a specific solution for nursery buildings, but also other buildings for small children i.e., kindergartens and preschools.

The limitation is the use of a perfect mixing model in simulations, which may not be obtained in reality. The simulation results were intended to illustrate the situation of increases and decreases in $\mathrm{CO}_{2}$ concentration in rooms during the presence of people. The selected air flows were larger than they resulted from the simulation due to the technical availability of solutions. The recommended solutions should be applied in existing buildings in order to confirm the research hypothesis. Examination of the proposed strategy will be the subject of further research.

\section{VENTILATION STRATEGY FOR NURSERIES IN EXISTING BUILDINGS}

Based on the data reported in this study, the following recommendations are proposed as a strategy to ensure the proper air quality in existing buildings used as nurseries: 
1) In nurseries that accommodate little children and there is a nap time in the middle of the day, the sleeping room should be separated, which allows shortening the time spent in the rooms to about 3 hours.

2) Airflow should be related to the number of children enrolled in the group. If the attendance factor will be used to determine this metric, the airflow should be $15 \mathrm{~m}^{3} \mathrm{~h}^{-1}$ per person and $12 \mathrm{~m}^{3} \mathrm{~h}^{-1}$ per person for a real attendance.

3) The above airflows, which serves only one room at a time, allows for no risk of $\mathrm{CO}_{2}$ contamination in the other rooms. Further, the capacity can be individually adjusted and requires a small amount of space for installation. It is necessary to make two holes in the external wall with a diameter of $200 \mathrm{~mm}$ in the smaller rooms $\left(<100 \mathrm{~m}^{3}\right)$ to four with a diameter of $200 \mathrm{~mm}$ in the largest rooms $\left(150 \mathrm{~m}^{3}\right)$. The volume of the room translates into the number of children that can attend the nursery which affects the size of the appropriate ventilation airflow.

4) The average concentration of $\mathrm{CO}_{2}$ in the room is determined at the level of $1000 \mathrm{ppm}$ which ensures that the ventilation has an adequate efficiency. It is allowed to temporarily increase $\mathrm{CO}_{2}$ concentration up to $1200 \mathrm{ppm}$, especially when all children are present, but only for a short period of time.

5) Nursery rooms should be equipped with $\mathrm{CO}_{2}$ concentration sensors that show the current $\mathrm{CO}_{2}$ concentration values and allow the staff to react when the $\mathrm{CO}_{2}$ concentration is exceeded. The sensors should be located in the zones where children are present. Staff should be trained to be able to respond when $\mathrm{CO}_{2}$ levels increase. If the concentration increases and reaches a value exceeding $1000 \mathrm{ppm}$, the caregivers should temporarily change the room and ventilate the previous room intensively, e.g., by opening a window (for fast reduction of $\mathrm{CO}_{2}$ ). Changing the room when the outdoor temperature is low, which could lower the internal temperature below a comfortable level, will increase discomfort and the risk of catching a cold for children. Optimally, the best solution is to increase the ventilation airflow. Often, in decentralized units, an increase in airflow may be associated with an increase in noise from the equipment, but such action should only take place in critical situations and should, therefore, be acceptable.

6) When $\mathrm{CO}_{2}$ concentrations are greater than $1200 \mathrm{ppm}$, it is recommended to increase the volume of the bedroom by opening the sleeping room door. Most often, bedrooms are separate rooms with closed doors. The closure of the room means that the children are not distracted and may fall asleep better. Data shows that an increase in $\mathrm{CO}_{2}$ concentration of more than 1200 ppm took place more than an hour after the start of the nap. This is the time when most children are asleep, so opening the door during this time and keeping the adjoining room quiet should not negatively affect nap time.

7) In the warmer period of the year, when the outside temperature is close to the internal temperature, and the outside air is not contaminated with particulate matter room airing can be used as an alternative to mechanical systems, which will reduce electricity consumption in the building.

The recommendations contained in the proposed strategy are based on the results of research conducted during the COVID-19 pandemic. By following the recommendations, appropriate conditions can be ensured and the risk of transmission of various infections can be reduced. However, this strategy is aimed at the proper operation of facilities during normal operation and is not recommended to prevent contracting the SARS-CoV-2 virus. Some recommendations for limiting the SARS-CoV-2 virus have been used as these are often good practices that should be followed in everyday life, not just in the face of pandemics.

\section{CONLUSIONS}

1) The importance of nurseries in the everyday life of parents and that it is extremely important to ensure the proper indoor air quality in these institutions - for the health of children and their proper development, and for ensuring the professional activity of parents of young children it was emphasized.

2) Factors important for ensuring proper air quality parameters were identified: the way the 
rooms are used, the duration of stay in a given room (shortening when two rooms are used by one group), the size of the room and air flow per person.

3) It was specified that the supply air flow should be related to number of people and not to the volume of the room.

4) It has been shown that airing the rooms with the assumption of keeping the $\mathrm{CO}_{2}$ concentration at an average level below 1000 ppm is more expensive than supplying air by decentralized units with heat recovery. Airing may be used when the outside air has a temperature close to the room temperature and is not polluted with particulate matter.

5) Ventilation units equipped with air filters provide at the same time the supply of purified air, which cannot be obtained when airing the rooms.

6) The proposed strategy uses the installation of small ventilation units in each room because in existing buildings it is difficult or impossible to use traditional central ventilation systems.

The analysis and simulations confirmed the thesis that decentralized ventilation can be a good and inexpensive solution to the problem in existing buildings with ensuring the proper quality of indoor air. The introduction of forced air exchange in the rooms of existing buildings used by young children ensuring healthy conditions should be obligatory despite the necessity to incur investment costs.

\section{ADDITIONAL INFORMATION}

\section{Funding Source}

This research was funded by the Polish Ministry of Science and Higher Education - research subsidy (grant number 504 101/0713/SBAD/0947).

\section{SUPPLEMENTARY MATERIAL}

Supplementary material for this article can be found in the online version at https://doi. org/10.4209/aaqr.210337

\section{REFERENCES}

Almilaji, O. (2021). Air recirculation role in the spread of COVID-19 onboard the diamond princess cruise ship during a quarantine period. Aerosol Air Qual. Res. 21, 200495. https://doi.org/10.42 09/aaqr.200495

Amanowicz, Ł., Wojtkowiak, J. (2020a). Thermal performance of multi-pipe earth-to-air heat exchangers considering the non-uniform distribution of air between parallel pipes. Geothermics 88, 101896. https://doi.org/10.1016/j.geothermics.2020.101896

Amanowicz, Ł., Wojtkowiak, J. (2020b). Approximated flow characteristics of multi-pipe earth-toair heat exchangers for thermal analysis under variable airflow conditions. Renewable Energy 158, 585-597. https://doi.org/10.1016/j.renene.2020.05.125

Asanati, K., Voden, L., Majeed, A. (2021). Healthier schools during the COVID-19 pandemic: Ventilation, testing and vaccination. J. R. Soc. Med. 114, 160-163. https://doi.org/10.1177/01 41076821992449

Aviv, D., Chen, K.W., Teitelbaum, E., Sheppard, D., Pantelic, J., Rysanek, A., Meggers, F. (2021). A fresh (air) look at ventilation for COVID-19: Estimating the global energy savings potential of coupling natural ventilation with novel radiant cooling strategies. Appl. Energy 292, 116848. https://doi.org/10.1016/j.apenergy.2021.116848

Badam (2017). Children, youth and family. Nursery age. https://badam.poznan.pl/en/i_city-andcommunity/nursery-age/ (accessed 27 October 2021).

Basińska, M., Michałkiewicz, M., Ratajczak, K. (2019). Impact of physical and microbiological parameters on proper indoor air quality in nursery. Environ. Int. 132, 105098. https://doi.org/ 10.1016/j.envint.2019.105098

Basińska, M., Ratajczak, K., Michałkiewicz, M., Fuć, P., Siedlecki, M. (2021). The way of usage and location in a big city agglomeration as impact factors of the nurseries indoor air quality. 
Energies 14, 7534. https://doi.org/10.3390/en14227534

Bettio, F., Plantenga, J. (2004). Comparing care regimes in Europe. Feminist Econ. 10, 85-113. https://doi.org/10.1080/1354570042000198245

Bhagat, R.K., Davies Wykes, M.S., Dalziel, S.B., Linden, P.F. (2020). Effects of ventilation on the indoor spread of COVID-19. J. Fluid Mech. 903, F1. https://doi.org/10.1017/jfm.2020.720

Blocken, B., van Druenen, T., van Hooff, T., Verstappen, P.A., Marchal, T., Marr, L.C. (2020). Can indoor sports centers be allowed to re-open during the COVID-19 pandemic based on a certificate of equivalence? Build. Environ. 180, 107022. https://doi.org/10.1016/j.buildenv.2020.107022

Blocken, B., van Druenen, T., Ricci, A., Kang, L., van Hooff, T., Qin, P., Xia, L., Ruiz, C.A., Arts, J.H., Diepens, J.F.L., Maas, G.A., Gillmeier, S.G., Vos, S.B., Brombacher, A.C. (2021). Ventilation and air cleaning to limit aerosol particle concentrations in a gym during the COVID-19 pandemic. Build. Environ. 193, 107659. https://doi.org/10.1016/j.buildenv.2021.107659

Brągoszewska, E., Mainka, A., Pastuszka, J.S. (2016). Bacterial aerosols in an urban nursery school in Gliwice, Poland: A case study. Aerobiologia 32, 469-480. https://doi.org/10.1007/s10453015-9419-x

Burridge, H.C., Bhagat, R.K., Stettler, M.E.J., Kumar, P., de Mel, I., Demis, P., Hart, A., JohnsonLlambias, Y., King, M.F., Klymenko, O., McMillan, A., Morawiecki, P., Pennington, T., Short, M., Sykes, D., Trinh, P.H., Wilson, S.K., Wong, C., Wragg, H., Davies Wykes, M.S., et al. (2021). The ventilation of buildings and other mitigating measures for COVID-19: A focus on wintertime. Proc. R. Soc. London, Ser. A 477, 20200855. https://doi.org/10.1098/rspa.2020.0855

Chen, Q.X., Huang, C.L., Yuan, Y., Tan, H.P. (2020). Influence of COVID-19 event on air quality and their association in mainland China. Aerosol Air Qual. Res. 20, 1541-1551. https://doi.org/10.4 209/aaqr.2020.05.0224

de Man, P., Paltansing, S., Ong, D.S.Y., Vaessen, N., van Nielen, G., Koeleman, J.G.M. (2021). Outbreak of coronavirus disease 2019 (COVID-19) in a nursing home associated with aerosol transmission as a result of inadequate ventilation. Clin. Infect. Dis. 73, 170-171. https://doi.org/10.1093/cid/ciaa1270

Elfer, P. (2006). Exploring children's expressions of attachment in nursery. Eur. Early Childhood Educ. Res. J. 14, 81-95. https://doi.org/10.1080/13502930285209931

Elfer, P. (2007). What are nurseries for?: the concept of primary task and its application in differentiating roles and tasks in nurseries J. Early Childhood Res. 5, 169-188. https://doi.org/ 10.1177/1476718X07076727

Elsaid, A.M., Ahmed, M.S. (2021). Indoor air quality strategies for air-conditioning and ventilation systems with the spread of the global coronavirus (COVID-19) epidemic: Improvements and recommendations. Environ. Res. 199, 111314. https://doi.org/10.1016/j.envres.2021.111314

European Commission Childcare Network (1988). Childcare and Equality of Opportunity. London.

Fadaei, A. (2021). Ventilation systems and COVID-19 spread: Evidence from a systematic review study. Eur. J. Sustainable Dev. Res. 5, em0157. https://doi.org/10.21601/ejosdr/10845

Geiss, O. (2021). Effect of wearing face masks on the carbon dioxide concentration in the breathing zone. Aerosol Air Qual. Res. 21, 200403. https://doi.org/10.4209/aaqr.2020.07.0403

Gettings, J., Czarnik, M., Morris, E., Haller, E., Thompson-Paul, A.M., Rasberry, C., Lanzieri, T.M., Smith-Grant, J., Aholou, T.M., Thomas, E., Drenzek, C., MacKellar, D. (2021). Mask use and ventilation improvements to reduce COVID-19 incidence in elementary schools - Georgia, November 16-December 11, 2020. MMWR Morb. Mortal. Wkly. Rep. 70, 779-784. https://doi.org/10.15585/mmwr.mm7021e1

Guo, M., Xu, P., Xiao, T., He, R., Dai, M., Miller, S.L. (2021). Review and comparison of HVAC operation guidelines in different countries during the COVID-19 pandemic. Build. Environ. 187, 107368. https://doi.org/10.1016/j.buildenv.2020.107368

Hayashi, M., Yanagi, U., Azuma, K., Kagi, N., Ogata, M., Morimoto, S., Hayama, H., Mori, T., Kikuta, K., Tanabe, S., Kurabuchi, T., Yamada, H., Kobayashi, K., Kim, H., Kaihara, N. (2020). Measures against COVID-19 concerning summer indoor environment in Japan. Jpn. Archit. Rev. 3, 423434. https://doi.org/10.1002/2475-8876.12183

Hu, W., Chen, Y., Chen, J. (2021). Short-term effect of fine particular matter on daily hospitalizations for ischemic stroke: A time-series study in Yancheng, China. Ecotoxicol. Environ. Saf. 208, 111518. https://doi.org/10.1016/j.ecoenv.2020.111518

Kayhan, N., Akmese, P.P. (2012). Examining the Preschool Educational Institutions in European 
Union Countries and in Turkey. Procedia Soc. Behav. Sci. 46, 1517-1521. https://doi.org/ 10.1016/j.sbspro.2012.05.332

Kohanski, M.A., Lo, L.J., Waring, M.S. (2020). Review of indoor aerosol generation, transport, and control in the context of COVID-19. Int. Forum Allergy Rhinol. 10, 1173-1179. https://doi.org/ 10.1002/alr.22661

Li, H., Shankar, S.N., Witanachchi, C.T., Lednicky, J.A., Loeb, J.C., Alam, Md.M., Fan, Z.H., Mohamed, K., Eiguren-Fernandez, A., Wu, C.Y. (2021). Environmental surveillance and transmission risk assessments for SARS-CoV-2 in a fitness center. Aerosol Air Qual. Res. 21, 210106. https://doi.org/10.4209/aaqr.210106

Madureira, J., Paciência, I., Pereira, C., Teixeira, J.P., de O. Fernandes, E. (2016). Indoor air quality in Portuguese schools: Levels and sources of pollutants. Indoor Air 26, 526-537. https://doi.org/10.1111/ina.12237

Minister of Labor and Social Policy (2019). Regulation of the Minister of Labor and Social Policy on the housing and sanitary requirements to be met by the premises where the nursery or children's club is to be run.

Mousavi, E.S., Godri Pollitt, K.J., Sherman, J., Martinello, R.A. (2020). Performance analysis of portable HEPA filters and temporary plastic anterooms on the spread of surrogate coronavirus. Build. Environ. 183, 107186. https://doi.org/10.1016/j.buildenv.2020.107186

Nazaroff, W.W. (2016). Indoor bioaerosol dynamics. Indoor Air 26, 61-78. https://doi.org/10. 1111/ina.12174

Okarska-Napierała, M., Mańdziuk, J., Kuchar, E. (2021). SARS-CoV-2 cluster in nursery, Poland. Emerging Infect. Dis. 27, 317-319. https://doi.org/10.3201/eid2701.203849

Oniwon, H.O.E. (2015). An examination of the role of nursery education on primary school pupils in Nigeria. J. Educ. Pract. 6, 77-81.

Park, S., Choi, Y., Song, D., Kim, E.K. (2021). Natural ventilation strategy and related issues to prevent coronavirus disease 2019 (COVID-19) airborne transmission in a school building. Sci. Total Environ. 789, 147764. https://doi.org/10.1016/j.scitotenv.2021.147764

Pease, L.F., Wang, N., Salsbury, T.I., Underhill, R.M., Flaherty, J.E., Vlachokostas, A., Kulkarni, G., James, D.P. (2021). Investigation of potential aerosol transmission and infectivity of SARS-CoV-2 through central ventilation systems. Build. Environ. 197, 107633. https://doi.org/10.1016/ j.buildenv.2021.107633

Penn, H. (1995). Nursery education: what is it for? Int. J. Educ. Manage. 9, 4-9. https://doi.org/ $10.1108 / 09513549510088444$

Penn, H., Simon, A., Lloyd, E. (2020). COVID-19 and childcare: Why many nurseries will struggle to weather the storm. British and Irish Politics and Policy | COVID-19 | Featured. https://blogs.Ise.ac.uk/politicsandpolicy/covid-19-and-childcare

Qian, H., Miao, T., Liu, L., Zheng, X., Luo, D., Li, Y. (2021). Indoor transmission of SARS-CoV-2. Indoor Air 31, 639-645. https://doi.org/10.1111/ina.12766

Ratajczak, K., Amanowicz, Ł., Szczechowiak, E. (2020). Assessment of the air streams mixing in wall-type heat recovery units for ventilation of existing and refurbishing buildings toward low energy buildings. Energy Build. 227, 110427. https://doi.org/10.1016/j.enbuild.2020.110427

Ratajczak, K., Basińska, M. (2021). The well-being of children in nurseries does not have to be expensive: The real costs of maintaining low carbon dioxide concentrations in nurseries. Energies 14, 2035. https://doi.org/10.3390/en14082035

REHVA (2021). REHVA COVID-19 guidance document. How to operate HVAC and other building service systems to prevent the spread of the coronavirus (SARS-CoV-2) disease (COVID-19) in workplaces. 2021.

Ren, J., Wang, Y., Liu, Q., Liu, Y. (2021). Numerical study of three ventilation strategies in a prefabricated COVID-19 inpatient ward. Build. Environ. 188, 107467. https://doi.org/10. 1016/j.buildenv.2020.107467

Schibuola, L., Tambani, C. (2021). High energy efficiency ventilation to limit COVID-19 contagion in school environments. Energy Build. 240, 110882. https://doi.org/10.1016/j.enbuild.2021. 110882

Silva, C., Freschi, E., Caselli, P. (2018). ECEC in the European Union: Analysis and governance of ECEC systems of four Member States. Form@re - Open Journal Per La Formazione in Rete 18, 234-247. 
Stabile, L., Pacitto, A., Mikszewski, A., Morawska, L., Buonanno, G. (2021). Ventilation procedures to minimize the airborne transmission of viruses in classrooms. Build. Environ. 202, 108042. https://doi.org/10.1016/j.buildenv.2021.108042

Sun, C., Zhai, Z. (2020). The efficacy of social distance and ventilation effectiveness in preventing COVID-19 transmission. Sustainable Cities Soc. 62, 102390. https://doi.org/10.1016/j.scs. 2020.102390

Sundell, J., Levin, H., Nazaroff, W.W., Cain, W.S., Fisk, W.J., Grimsrud, D.T., Gyntelberg, F., Li, Y., Persily, A.K., Pickering, A.C., Samet, J.M., Spengler, J.D., Taylor, S.T., Weschler, C.J. (2011). Ventilation rates and health: Multidisciplinary review of the scientific literature. Indoor Air 21, 191-204. https://doi.org/10.1111/j.1600-0668.2010.00703.x

Torres, A. (2008). Women, gender, and work: The portuguese case in the context of the European Union. Int. J. Sociol. 38, 36-56. https://doi.org/10.2753/IJS0020-7659380402

Villanueva, F., Notario, A., Cabañas, B., Martín, P., Salgado, S., Gabriel, M.F. (2021). Assessment of $\mathrm{CO}_{2}$ and aerosol $\left(\mathrm{PM}_{2.5}, \mathrm{PM}_{10}\right.$, UFP) concentrations during the reopening of schools in the COVID-19 pandemic: The case of a metropolitan area in Central-Southern Spain. Environ. Res. 197, 111092. https://doi.org/10.1016/j.envres.2021.111092

Wang, J., Huang, J., Feng, Z., Cao, S.J., Haghighat, F. (2021a). Occupant-density-detection based energy efficient ventilation system: Prevention of infection transmission. Energy Build. 240, 110883. https://doi.org/10.1016/j.enbuild.2021.110883

Wang, P., Zhao, Y., Li, J., Zhou, Y., Luo, R., Meng, X., Zhang, Y. (2021b). Prenatal exposure to ambient fine particulate matter and early childhood neurodevelopment: A population-based birth cohort study. Sci. Total Environ. 785, 147334. https://doi.org/10.1016/j.scitotenv.2021. 147334

Zender-Świercz, E. (2021a). A review of heat recovery in ventilation. Energies 14, 1759. https://doi.org/10.3390/en14061759

Zender-Świercz, E. (2021b). Assessment of indoor air parameters in building equipped with decentralised façade ventilation device. Energies 14, 1176. https://doi.org/10.3390/en1404 1176

Zhai, Z. (2020). Facial mask: A necessity to beat COVID-19. Build. Environ. 175, 106827. https://doi.org/10.1016/j.buildenv.2020.106827

Zhao, B., Liu, Y., Chen, C. (2020). Air purifiers: A supplementary measure to remove airborne SARS-CoV-2. Build. Environ. 177, 106918. https://doi.org/10.1016/j.buildenv.2020.106918 